\title{
Five Roles of an Information System: A Social Constructionist Approach to Analysing the Use of ERP Systems
}

\author{
Linda Askenäs and Alf Westelius \\ Linköping University, Linköping, Sweden
}

linas@ida.liu.se alfwe@ida.liu.se

\begin{abstract}
This paper presents a novel way of thinking about how information systems are used in organisations. Traditionally, computerised information systems are viewed as objects. In contrast, by viewing the information system as an actor, the understanding of the structuration process increases. The user, being influenced by the ERP (Enterprise Resource Planning) system and giving it an actor role, thereby also confers agency on the ERP system; through its very use it influences actions and thus also the structure. Based on a case study of ERP use in an ABB company over a decade, five different roles played by the ERP systems were identified. The ERP systems acted as Bureaucrat, Manipulator, Administrative assistant, Consultant or were dismissed (Dismissed) in the sense that intended users chose to avoid using them. These terms are defined in the full text.

The purpose of this approach here is not to "animate" the information systems, to give them life or a mind of their own, but rather to make explicit the socially constructed roles conferred on them by users and others who are affected by them. On this basis, it is possible to suggest how the roles can help us open up new areas of exploration concerning the fruitful use of IT.
\end{abstract}

Keywords: Interpreting information systems; Structuration theory; ERP systems; Information systems use; Actor; Social construction; Grounded theory; Case study; Longitudinal research

\section{Introduction}

This paper presents and discusses the influence that information systems have on the organising process in an $\mathrm{ABB}$ company over a decade. It focuses on the interaction between the use of information systems and the organising of the company. (The ABB Group, employing about 160,000 people in more than 100 countries, serves customers in power transmission and distribution; automation; oil, gas, and petrochemicals; building technologies; and in financial services. The subsidiary company studied in this arti-

Material published as part of this journal, either on-line or in print, is copyrighted by the publisher of Informing Science. Permission to make digital or paper copy of part or all of these works for personal or classroom use is granted without fee provided that the copies are not made or distributed for profit or commercial advantage AND that copies 1) bear this notice in full and 2) give the full citation on the first page. It is permissible to abstract these works so long as credit is given. To copy in all other cases or to republish or to post on a server or to redistribute to lists requires specific permission and payment of a fee. Contact Editor@inform.nu to request redistribution permission. cle produces large components for the power transmission and distribution sector.)

Use and usefulness of information systems differ. Previous research has attempted to establish causal relations between prerequisites for use, such as technical quality, information quality, and use, user satisfaction and impact (DeLone \& McLean, 1992). Others have concentrated on the relationship between user participation and use, or other indicators of system success. (Tait \& Vessey

Editor's Note: This paper replaces the paper originally published in Volume 4, Issue 3 pages 105-113 of the Informing Science Journal and first appeared as: Askenäs, L., \& Westelius, A. (2000). Five Roles of an Information System: a Social Constructionist Approach to Analyzing the Use of ERP Systems. In Proceedings of the Twenty-first International Conference on Information Systems, P. Weill, W. Orlikowski, S. Ang, H. Krcmar, and J. I. DeGross (eds.), Brisbane, Australia, December 2000, pp. 426-434. 
(1988), DeLone (1988), Hartwick \& Barki (1994), and McKeen, Guimeraes \& Wetherby (1994) are examples of quantitative research; Hirschheim (1985) and Westelius (1996) are examples of qualitative approaches). In all these studies the computerised information system is viewed as an object; a technical construction that is to be used by people. The information system itself does not take an active part in the processes studied. In this article we take a social constructionist stance (Berger \& Luckman, 1967). In organisations, people talk of the information systems as if they were intentional beings. Based on that observation, we explore the ways information systems are perceived by their direct and indirect users. In actor network theory, information systems are also considered to be actors interacting with other technological and social elements of the network, and descriptions of how the information system acts as change agent or enemy to those who want change in the organisation have been provided (Hanseth $\&$ Braa, 1998). Our exploration goes further and, building on Askenäs (2000), proposes five roles that an information system may be allowed to take in an organisation: Bureaucrat, Manipulator, Administrative assistant, Consultant and Dismissed. Dismissed signifies an information system that is not used at all by some or all intended users. These roles are specific to the relation between the information system and an individual or a group of people. Different individuals in the organisation may see the IS as having different roles. Therefore, these roles may coexist. We suggest that the way an information system is used is influenced by the perceived fit between the structure in the company and the IS functionality on the one hand, and the user's perception of how the system is trying to influence the user's work on the other hand.

Structure is enacted or modified continuously (Giddens, 1984). One increasingly important part in this flow of thoughts and actions is the plethora of information systems that surround us (Orlikowski \& Baroudi, 1991; Orlikowski, 1992). The information systems may be used in a way that matches or does not match the organisational structure and business logic. We label this "IS fit with structure." Individuals may also be directed or limited in their actions by the information system or employ it in ways that support, but do not control, the way the work is performed. This we term "Direction of control".

We choose to place these two - IS fit with structure and Direction of control - as two dimensions with a range from Good fit to Poor fit, and from IS controls to Individuals control, and thus we can identify four different situations, represented by the quadrants, for the role the information system may take relative its user. (See Figure 1) The information system may be viewed as being in control and either used in a way that supports the existing structure - routines and processes - or in a way that clashes with them. In a similar way an information system that is viewed as an optional support rather than as being in control may be more or less in line with the existing way of working.

Who is viewed as being in charge? This is to a large degree a subjective matter, a matter of perception. The more knowledgeable the user is regarding the information system and the business processes and tasks, the easier it is to gain a sense of control. The other dimension is also, to some extent, a mentally constructed one. The user with a better understanding of a system may find and use functionality that supports the actual way of working, whereas someone with a poorer understanding of the program (and/or the business) may fail to detect how the system can be used to support the existing way of working. However,

\section{Direction \\ of control}

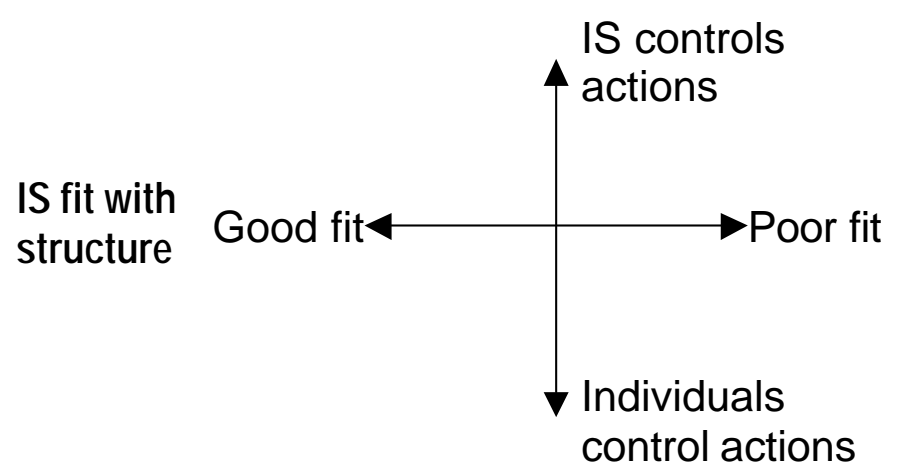

Figure 1. Dimensions affecting user perception of information systems 
the actual functionality made possible by the system plays a larger role along this dime nsion than along the other. An accounting system set up to support a product focused, batch processing oriented business may be difficult to use if the orientation is altered towards customer focus and an orderoriented mode of operation. An MRP (Material Requirements Planning) system set up to support order-based production may be difficult to use to support forecast-based production.

Four of the five roles we identify that information systems are perceived to play match the quadrants of Figure 1. The mapping of roles to quadrants is displayed in Figure 2. In the upper half of the figure, when the IS controls actions, the Bureaucrat stands for good fit between IS and structure, and the Manipulator for poor fit. In the bottom half of the figure, the Consultant stands for good fit and the Admi nistrative assistant for poor fit. The fifth role, the Dismissed, is the role played by an information system that is disregarded or ignored by its intended users. It does not match a specific quadrant and is thus not depicted in the figure. We will return to the five roles later on, but Table 1 provides a brief introduction to them here.

\begin{tabular}{|l|l|}
\hline Bureaucrat & $\begin{array}{l}\text { A bureaucrat is an official who adheres strictly to the rules and prin- } \\
\text { ciples laid down for him, rather than making individual considera- } \\
\text { tions. An ERP system given the role of a bureaucrat maintains the } \\
\text { structure in the organisation. It makes certain that the enactment of } \\
\text { structure conforms to the existing rules. This may, at times, seem } \\
\text { inflexible. However, unlike the manipulator, the structure it enforces } \\
\text { is one accepted by its users. }\end{array}$ \\
\hline Manipulator & $\begin{array}{l}\text { A manipulator is someone who controls, directs or influences others } \\
\text { in a way that is not entirely of their choosing. The ERP system may } \\
\text { be given the role of a manipulator if it is allowed to change or con- } \\
\text { serve work processes in ways not intended or wished by its users. If } \\
\text { someone, with or without external pressure, feels bound to using the } \\
\text { ERP system, it may take the Manipulator role. }\end{array}$ \\
\hline Consultant & $\begin{array}{l}\text { A consultant is someone contracted to perform specific, nontrivial } \\
\text { tasks, and to advise. The consultant is neither responsible for, nor in } \\
\text { command of, the work the organisation performs. An ERP system } \\
\text { acting as a consultant provides the user with options and with solu- } \\
\text { tions tailored to the situation. The use of the system follows the } \\
\text { user's wishes and leaves the user in control. For this to happen, the } \\
\text { user will have to understand the advice provided and be in a position } \\
\text { to exercise the freedom of choice. }\end{array}$ \\
\hline
\end{tabular}




\begin{tabular}{|l|l|}
\hline $\begin{array}{l}\text { Administrative } \\
\text { assistant }\end{array}$ & $\begin{array}{l}\text { An administrative assistant is someone who takes care of less com- } \\
\text { plicated tasks in an orderly way. An ERP system given the role of an } \\
\text { administrative assistant is not used to the same extent as those acting } \\
\text { as manipulators or bureaucrats. The information system administers } \\
\text { and simplifies record keeping and dissemination of data, but does } \\
\text { not affect (or indeed reflect) the processes and structures of the or- } \\
\text { ganisation in any fundamental way. The user takes a more active } \\
\text { role and the computerised information system is put to limited use } \\
\text { only. }\end{array}$ \\
\hline Dismissed & $\begin{array}{l}\text { The dismissed is someone who temporarily has been dismissed from } \\
\text { work, but may be reinstated at some later point in time. It is not used } \\
\text { at all by some or all intended users. The ERP that is dismissed be- } \\
\text { comes redundant. There may be many reasons for this but, to keep } \\
\text { dismissing the system, the user will need good reasons or have a } \\
\text { strong bargaining position. Buying and installing an ERP system is } \\
\text { costly, and the Dismissed system provides no return on the invest- } \\
\text { ment in it. }\end{array}$ \\
\hline \begin{tabular}{l} 
Table 1. Five identified roles of an ERP system \\
\hline
\end{tabular}
\end{tabular}

It is through the use to which technology is put, and the picture people form of technology, in interaction with the technology and in interaction with each other, that it influences the organisation of work.

"The risk of a technology driven development of working life stems from motivated actors, with a lack of organisational knowledge, who confer a certain significance on the technology, rather than technology itself driving the development." (Löwstedt, 1989, p.10)

The presentation of the roles played by information systems is based on a case study of the use and development of ERP systems in a Swedish manufacturing company in the ABB group. The history goes back several decades, but the focus of the study is on the last decade.

\section{Method}

In case study research, good access to the organisation is crucial: access that allows the researcher to follow the course of events in history and develop an understanding of the processes and the people (Gummesson, 1991). A research project studying how six ABB companies controlled their production was carried out in 1997. One focus in that study was to develop an understanding of how the companies used information systems to control their manufacturing organisations (Svensson, 1997). For the present study, one of these ABB companies was selected because it had changed information systems some years ago, had reorganised, seemed to be worth further study and was interested in participating in continued research.

The empirical work was done in the spring of 1999. Fifteen face-to-face interviews lasting 2-5 hours were conducted with a range of people in the organisation: the company division manager, purchasing manager, IT-manager, project manager, head planner, operation planner, salespeople, IT-staff, middle manager, production leader, constructor, controller, accounting manager, and order planner. Some, but not all, had been members of the ERP project. The interviews were semi-structured, starting with the person being asked to tell briefly their story of what had happened during the last decade and then answering more specific questions from the researcher. The resulting case description was presented to the 


\section{Askenäs \&f W estelius}

interviewees, who verified it. The case study was built using a grounded approach with exploratory ambitions (cf. Glaser \& Strauss, 1967). The analysis was based on the exploration of metaphors as well as on social constructionist interpretation (cf. Norén, 1995). The work was inspired by the analysing model of Tsoukas (1991), and the basic me taphor explored was that of the information system as an actor in the organising process.

\section{The Company Story}

At the beginning of the 1990s, the company experienced a tough period. Even though the company received more customer orders than ever, it was loss-making.

"Why did the company have such difficulty earning money, although we had production volume? We had a lot of technical problems and other trouble. It was so expensive to resolve problems and delays. We were known for always being late, and internally we were criticised a lot." (Company Division Manager)

The logistics manager in the division wanted to control production with the MRP technique and to get the operations to work like machinery. He received support for his ideas from the former division manager and company CEO and they agreed that investing in a new enterprise system was necessary to implement the ideas. At that time, they had a corporation enterprise system, AROS, which had first been developed in 1960. Originally, it had been developed to fit the organisation. By 1990, however, although AROS had been adapted over time, it no longer worked well in the organisation. At the beginning, the AROS system was a homogeneous, well-integrated system. Over time components had been added and different departments undertook further development. As it evolved, it became a complex system that was difficult to understand. ${ }^{1}$

"It seems ridiculous to those who haven't been involved, but at that time you did what the computer told you to do. The purchasers had no knowledge in material control principles. They were locked to what AROS supported them with and had no idea what happened in the program." (Purchasing manager)

"In the management team, we were very frustrated over not having sufficient information to manage the company. We asked for rather elementary information. They said: 'Sorry you can't have it'. The situation was impossible." (Company Division Manager)

The AROS system had, in some sense, power over the organisation. It refused to give the employees the information they needed and became a hindrance to organisational change. The Company Division Manager called AROS "Jack in the box" because a change in one part in the system often resulted in failure in another part. Experiencing difficulties in getting the products to customers on time, and problems in monitoring and managing the organisation as a whole, the employees had developed a "quick fix" culture to work around the system. For example, to speed up an important order they would borrow material between production orders without registering this in AROS.

A project called BLICK started in 1992 with the aim of introducing software that supported Materials Requirement Planning. Process analysis was undertaken, but the decision on which ERP system to implement was taken quickly and unmethodically. One consultant said it was not important which system to invest in if it had support for the MRP technique. Since a sister organisation was buying Triton from

\footnotetext{
${ }^{1}$ This may seem far removed from today's ERP implementations. ERP systems are often presented as integrated, modular systems. However, many implementations tend to be combinations of modules from ERP vendors and IS components existing in the company. This, together with often far-reaching company-specific modifications of the ERP modules, makes it difficult for the company to take full advantage of the ERP vendor's further development of the commercial software. The resulting situation then resembles what $\mathrm{ABB}$ experienced with AROS.
} 
Five Roles of an Information System

BAAN, the BLICK managers decided on Triton too. However, BAAN could not deliver the required functionality, and the implementation, planned for 1994, was postponed to 1996. By 1996, the organisation had changed, and the training in 1993 of the employees on the system and the MRP principles was forgotten.

"We should have started the training all over again, but there was no backing for such measures by management. ... They wanted to get this delayed project finished as soon as possible." (ITmanager)

The Triton system that was implemented in 1996 was set up according to the configuration decided by the project members in 1993. Once again it was a system that didn't support the organisation, but the project group sought to change the organisation. The installation of Triton was forced on most of the employees and compelled them to operate in new ways.

"At the outset, Triton almost became a dirty word." (Production leader)

For every quotation, the salespeople were meant to configure a specification in Triton. This took time and they could not spend as much time selling as they wanted. Shortly after the implementation they refused to use Triton. Other employee groups accepted the system but it was also extensively modified. Triton hindered the employees from returning to the "quick fix" culture. The operators had to finish one order before they could start another order, and the accountants were able to monitor and manage the planners' and operators' actions.

"If we just correct data and guess what it should be, then incorrect data will just continue cropping up. ... That's why we always try to locate who the incorrect transaction came from." (Accounting ma nager)

The purchaser even made use of the possibility to employ different replenishment models for different materials based on the features of each material.

"In one way the system change was a psychological revolution. You started to understand what you where doing. Today when you ask them, they actually tell what they are up to. ... They even start to question our initial decision to use the MRP technique for all materials." (Purchase ma nager)

The operation planner of the production, though, only used the system selectively. He was supposed to use Triton, but instead he extracted data to an Excel program and planned the production on his own. Then he informed Triton of the production order.

"We prepare the operation plan using Excel. We don't think that Triton supports the operation planning well enough. It's intended that Triton should calculate the timing of the start of an order but there are so many strange things. The system can't take everything into consideration and the real world is much more flexible." (Operation planner)

By the late 1990s, the company was one of the few that managed to reach the ambitious profit goals set by the ABB Corporation. It had more than doubled the amount of orders without increasing the number of employees. At present, it seems like a success story, but as the accounting manager put it, it is a journey on which you can never relax and think that it is over.

"I think that if you don't care enough you soon end up again with a system that no one understands. ... It's important that you systematically train and refresh the knowledge of the employees. We have a rather high employee turnover rate, and you easily forget that." (Accounting manager) 


\section{The Five Roles}

The roles presented below are the result of an analysis based on viewing the ERP system as an actor. Building on recollections of a process spanning more than one decade has made it possible to note how the two information systems changed in character.

\section{Manipulator}

We would define the first system, AROS, as a manipulator in the early 1990s. Originally, the system had been tailored to suit the business processes, but as the business changed, the system was modified up to a point when the systems analysts could no longer understand and control the complexity of the resulting patchwork. Further changes led to unexpected errors and problems somewhere else. Then, suggestions for improvements in the company were turned down because the IS staff could not make the necessary alterations in AROS. When this Manipulator was fired, the BLICK project enthusiasts set up the new system (Triton) in a way that they thought would help increase efficiency in the company. Triton required its users to work in a new way, which they resented.

Our interpretation is that both systems were Manipulators. The old one tried to conserve old ways of working, the new one tried to change the way work was done. Both were allowed to succeed to some extent.

\section{Bureaucrat}

As time passed, people adapted to the Triton way of working, and the way Triton was set up was modified to some extent. There are statements from those interviewed attesting that Triton kept law and order and rooted out the "quick fix mentality". When using the old system, it often happened that material was "borrowed" between orders without the changes being entered into the system. The new ERP system restricted such behaviour. In Triton the whole order and production process broke down immediately if an order was assembled using material from another order. The go ahead to start assembling would not be issued unless all material was present and correctly entered into the system. The data was sufficiently correct to make irregularities show clearly, and it was easy to demonstrate quantitatively the negative effects of unofficial improvisations. The workers also began to see the interconnections in the business process more clearly. The ERP system acted as a true bureaucrat.

\section{Administrative Assistant}

Not everywhere was the ERP system given the opportunity to act as a bureaucrat. The shop planner felt that Triton was trying to take over the detailed production planning. However, the system was not very good at planning; the lead times became too long and it was not possible to adjust the capacity of different stations (as when moving people between tasks). The planner then extracted all the job orders from the system, planned manually and keyed in the resulting plan. He thus used Triton to administer the data, but not for the more complex parts of his task. It relayed data to him from the head planner, the order planner and the configurer. The finished plans that he subsequently entered were relayed by Triton to the material planners and the assembly workers.

Thus, the ERP system was not allowed to control or even support the actual production planning. It only supported record keeping in an orderly fashion, and made possible the electronic communication between the order planner and the other functions - a purely administrative role. 


\section{Consultant}

During the spring of 1999, the Triton-facilitated procurement practice was beginning to be questioned. People started investigating other ways of carrying out the activities. With AROS they had been confined to the AROS way of working, and did not understand enough of the logic behind the activities to question the way things were done. Later, they had been subjected to training in different material requirement planning techniques and how to operate Triton under the different techniques. This made them question the way the system was set up, and they learned how to adjust Triton to support different planning techniques for different materials. The system was no longer a true Bureaucrat; it had turned into a Consultant. The users could employ the competence built into the system at will and receive support for the kind of planning and control they felt was appropriate.

\section{Dismissed}

The salespeople refused to have a Manipulator or Bureaucrat as colleague. Triton required them to enter detailed information on prospects and potential orders before making proposals and closing deals.

Manufacturability of orders should be confirmed by the planners and scheduled delivery dates calculated before the salesperson could proceed. In principle, this would have been beneficial for the company, but claiming that the workload for entering the data required was excessive, the salespeople dismissed Triton almost from the start.

Being the ones who actually close the deals with the customers, thereby generating the company's income, the salespeople had a strong bargaining position. More administration for them would mean reduced income for the company in the short run. However, in the long run the managers want the salespeople connected to the electronic flow of information in the company. They will not be allowed to dismiss the ERP system indefinitely. In due course they will receive a tailor made application instead that will intermediate between them and the ERP system.

\section{The Use of ERP Systems}

An ERP system is a business tool, but in the way it should be used by many individuals in the organisation, it becomes a tool with far-reaching influence of its own (cf. Kling \& Scacchi, 1982; Huges, 1987; Orlikowski \& Gash, 1994; Robey \& Azevedo, 1994; Sahay, Palit \& Robey, 1994). It is not possible for all individuals to change the system according to their personal wishes. In that sense, an information system in use will never be able to adapt totally to every individual's wishes. Here we attempt to show how the fives roles together form a vocabulary for discussing the role played by the ERP system in relation to its users.

\section{The Five Roles and Structuration}

Following Giddens (1984), we use the term structuration to denote the process of reproduction of a social system. The actors' enactment of structure can reproduce the structure rather unchanged, but actors can also create variations or changes, leading to a transmutation rather than to continuity. An ERP system playing the role of the dismissed takes no part in either reproduction or transmutation of the structure nor in the choices leading to the one or the other; it does not affect the structuration process of the organisation at all. It is completely left out of it, and leaves the field open to conservative or modifying forces. Naturally, it is not a role that would be desired by those deciding to purchase and implement a system. However, all the other four roles may have a legitimate place. The Administrative assistant does not provide its user with much support and does not play a significant role in the enactment of structure. For tasks with much variability or for highly complex tasks it may be difficult to provide efficient, computerised information system support at a reasonable cost. The system taking the administrative assistant 


\section{Askenäs \&f W estelius}

role can then still provide some support without interfering too much with the way the user wants (or needs) to work. In the administrative assistant role it can also make possible the integration of the non computer supported task in an otherwise computer aided process.

The Bureaucrat and the Manipulator affect the structuration process, but in different ways. The Bureaucrat reinforces the existing structure by directing enactment to be consistent with the existing recommended procedures. The Manipulator, on the other hand, steers enactment away from the way the user intends or wants to act, towards ways that the system endorses. Above, we have described how this manipulation could be experienced as both negative and positive, depending on the individual's perspective and on the change the Manipulator is bringing about. In Hanseth \& Braa (1998), the ERP system SAP is described first as a powerful change agent helping top management bring changes about. Later on, SAP is described as everybody's enemy, resisting all organisational change. We would say that in relation to the users, SAP was a Manipulator in both situations. At first, it slowly forced people to modify their enactment of structure in directions they felt uncomfortable with, and then by forcing a consistent reenactment of the existing structure even when people felt that change was called for (just as in the late days of AROS).

The Consultant, finally, influences structuration by increasing the choices available to the user and by supporting different courses of action. The resulting structure becomes richer - more flexible, more diverse, more responsive, more complex - and less predetermined than under either Bureaucrat or Manipulator rule, but could lead to more consistent behaviour than when the information system is given the roles of Administrative assistant or Dismissed, since in those cases there is little or no influence on the enactment of structure by the information system.

\section{The Five Roles and Individuals}

We propose that the use of an ERP system affects the structuration of the organisation. However, the ERP system does not act on its own. It is individuals who use it and it is thus the individuals who may give it a role as an actor. The ERP system is not an independent and invariant, externally designed actor. It receives its character in interaction with the structure of the organisation, the other information systems - forming an infrastructure together with them (cf. Hanseth \& Braa, 1998) - and in interaction with its users. The user, being influenced by the ERP system and giving it an actor role, consciously or not, thereby also confers agency on the ERP system - as it is used, it is allowed to influence actions and thus also the structure (cf. Giddens, 1984). Unintended and unacknowledged consequences of the use of the system exist simultaneously with rational use of the system by the individuals.

An ERP system playing the Dismissed role has been actively rejected by an individual. To enable a system to play Manipulator the individuals have to obey and follow the instructions in the system. This may be done consciously and reluctantly or unknowingly and thus without questioning the manipulation (cf. the obvious manipulation by the newly installed Triton and the gradually increasing, at first imperceptible, manipulation by the ageing AROS).

A Bureaucrat system also needs the individuals to follow its instructions, but here the users basically agree with the instructions. Thus the power and sanctions from the system, or individuals wanting others to use the system, do not need to be as strong as in the Manipulator role. In the Administrative assistant role the system, on the other hand, does not have power over the individuals; instead the individuals use the system as they like, and only selectively. It is used to supply data and record results of decisions, rather than to play an active part in the activities the user performs. The Consultant role, finally, is between Administrative assistant and Bureaucrat regarding its influence on the actions of the individual. The user lets (or makes) the system suggest alternative actions, but chooses between the alternatives offered rather than circumventing them altogether. The support offered by the system, and requested by its user, is substantive and plays an important part in the user's work. 
Individuals have different perceptions and understandings of the purpose of information systems (Orlikowski \& Gash, 1994). In the ABB case, the system certainly played different roles in the different departments. It was dismissed by the salespeople; to the operators it was a Bureaucrat; for the production planner it was an Administrative assistant; the purchasers turned it into a Consultant. Are there also large individual differences within a department? Other case studies have demonstrated such differences, and an analysis by Askenäs (2000) of such a study published by Gäre (1999) showed that these individual differences could be attributed to differences in knowledge: knowledge of the ERP system and knowledge of the work. This interesting area warrants further exploration.

\section{Discussion}

The five roles we suggest provide an addition to the language to stimulate nuanced discussion of the interplay between the use of ERP systems and organisational change. The labels we have chosen emphasise the perceived roles of the information systems as actors (helping or hindering) and make these roles explicit. The purpose is not to "animate" the information systems, to give them life and a mi nd of their own, but rather to make explicit the socially constructed roles conferred on them by users and others who are affected by them. The labels make it natural to pose questions like:

"What should we do to stop the Bureaucrat from becoming Manipulator?" or

"Is it realistic and cost effective to aim at providing the planner with an ERP system as Consultant, or should we just aim for an Administrative assistant role?"

Managers attending an executive MBA program started discussing:

"How can we encourage the placing of the ERP system in the Manipulator role to speed up organisational transformation?"

Many people feel that the current ERP system has taken (or been given) a role that hinders or does not support the business processes to the extent desired. The role an individual confers on the system is partly due to the combination of business and information system knowledge of the individual, partly due to the socially constructed image of the system in a group of fellow workers, and partly based on the functional support the information system is capable of. This observation could lead to alternative solutions to the problem. The revolutionary approach of replacing the system may at first seem like an obvious and effective solution. However, an evolutionary approach consisting of training, dialogue and reflection concerning the business processes, the ERP system and the interplay between the two, could often be a better choice. Hanseth \& Braa (1998) observed a drift from a useful to a restricting role of SAP at Norsk Hydro. At ABB we also observed a move from more to less desired roles over time. If we do not do anything, it is probable that the system will move from a good consultant to a competent but unimaginative bureaucrat, or become degraded to an administrative assistant. It is likely to move from a useful bureaucrat to an annoying and overly conservative manipulator. Perhaps a lack of focus on continued user training and on discussion among users makes us feel that we are restricted by the system too early or maybe even completely unnecessarily. Through the new conceptual language developed in this paper, we hope to stimulate the exploration of these dynamics: the patterns of changes, the factors influencing them, and their consequences.

\section{References}

Askenäs, L. (2000). Enterprise systems: The technology's active and passive role in an organization (in Swedish: Affärssystemet - en studie om teknikens aktiva and passiva roll i en organisation), lic.-avh. No. 808, IDA-EIS, Linköping University and Institute of Technology, Linköping, Sweden.

Berger, P., \& Luckmann, T. (1967). The social construction of reality: A treatise in the sociology of knowledge. London: Penguin Books. 


\section{Askenäs \&f W estelius}

DeLone, W. (1988). Determinants of success for computer usage in small business. MIS Quarterly, 12 (1), 50-61.

DeLone, W., \& McLean, E. (1992). Information systems success: The quest for the dependent variable. Information Systems Research, 3 (1), 60-95.

Gäre, K. (1999). Verksamhetsförändringar i samband med IS-införande (in Swedish), lic.-avh. No. 791, IDA-EIS, Linköping University and Institute of Technology, Linköping, Sweden.

Giddens, A. (1984). The constitution of society: Outline of the theory of structuration. Cambridge, England: Polity Press.

Glaser, B., \& Strauss, A. (1967). The discovery of grounded theory. Chicago: Aldine.

Gummesson, E. (1991). Qualitative methods in management research (revised ed.). Newbury Park, CA: Sage Publications.

Hanseth, O., \& Braa, K. (1998). Technology as traitor: Emergent SAP infrastructure in a global organization. In R. Hirschheim, M. Newman, \& J. I. DeGross (eds.), Proceedings of the Nineteenth International Conference on Information Systems. Helsinki, Finland, December, pp. 188-196.

Hartwick, J., \& Barki, H. (1994). Explaining the role of user participation in information systems use. Management Science, 40 (4), 440-465.

Hirschheim, R. (1985). User experience with and assessment of participative systems design, MIS Quarterly, 9 (4), 295-304.

Huges, T. P. (1987). The evolution of large technical systems. In W. E. Bijker, T. P. Hughes, \& T. J. Pinch (eds.), The Social Construction of Technological Systems: New Directions in the Sociology and History of Technology. Cambridge, MA: MIT Press.

Kling, R., \& Scacchi, W. (1982). The web of computing: Computer technology as social organization. In M. C. Yovits (ed.), Advances in Computers. New York: Academic Press, pp. 2-85.

Löwstedt, J. (1989). Organisation och teknikförändring - En inledning (in Swedish), Organisation och teknikförändringinternationella jämförelser av arbetsorganisationer i tjänstesektorn, J. Löwstedt (ed.), Lund: Studentlitteratur.

McKeen, J., Guimaraes, T., \& Wetherbe, J. (1994). The relationship between user participation and satisfaction: An investigation of four contingency factors. MIS Quarterly.

Norén, L. (1995). Tolkande företagsekonomisk forskning en metodbok: social konstruktionism, metaforsynsätt, aktörssynsätt (in Swedish), Lund: Studentlitteratur.

Orlikowski, W. (1992). The duality of technology: Rethinking the concept of technology in organizations. Organization Science, 3 (3), 398-427.

Orlikowski, W., \& Baroudi, J. (1991, March). Studying information technology in organizations: Research approaches and assumptions. Information Systems Research, 2 (1), 1-28.

Orlikowski, W., \& Gash, D. (1994). Technological frames: Making sense of information technology in organizations. ACM Transactions on Information Systems 12 (2), 174-207.

Orlikowski, W., \& Robey, D. (1991, June). Information technology and the structuring of organizations. Information Systems Research, 2 (2), 143-169.

Robey, D., \& Azevedo, A. (1994). Cultural Analysis of the Organizational Consequences of Information Technology. Accounting Management and Information Technology, 4 (1), 23-37.

Sahay, S., Palit, M., \& Robey, D. (1994). A relativist approach to studying the social construction of information technology. European Journal of Information Systems, 3 (4), 248-258.

Svensson, L. (1997). På väg mot en produktion i världsklass - en studie i MPS på ABB (in Swedish). Examensarbete LiTHIDA-Ex-97/11, Linköping University, Linköping, Sweden.

Tait, P., \& Vessey, I. (1988). The effect of user involvement on system success: A contingency approach. MIS Quarterly, 12 (1), 90-107.

Tsoukas, H. (1991). The missing link: A transformational view of metaphors in organizational science. Academy of Management Review, 16 (3), 566-585.

Westelius, A. (1996). A study of patterns of communication in management accounting and control projects. EFI, Stockholm School of Economics, Stockholm, Sweden. 


\section{Biographies}

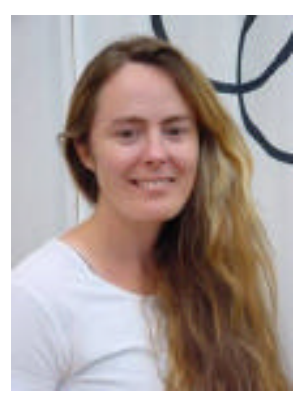

Linda Askenäs is Ph. D student at the Computer and Information Science Department (IDA), in the division Information Systems Management (ISM), at Linköpings universitet in Sweden. She is also associated with the International Graduate School of Management and Industrial Engineering (IMIE). Linda's research interest is in the interaction of organizations and information technology, with particular emphasis on dynamics of structures, individuals and technology. She has also developed and is teaching an undergraduate course in ERP-system selection, implementation and use.

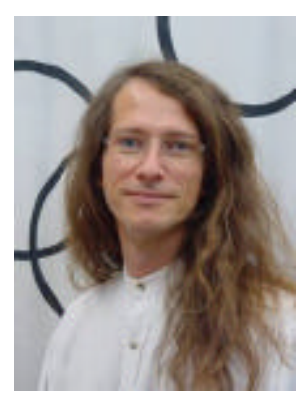

Alf Westelius is Assistant Professor in Information Systems Management at Linköpings universitet in Sweden. He earned his Ph.D. at the Stockholm School of Economics and has worked with systems development and management of change in the private and public sectors as well as in NPOs. Alf's research interests include organisational change projects where IT is an important factor, and people's images and understandings of their work, their organisations and of information systems. 